\title{
CREATINC AND ENHANCING CAPACITY IN AFRICA FOR EFFICIENT ECONOMIC AND SOCIAL DEVELOPMENT
}

LAWALLEY COLE

COALITION ON MEDIA AND EDUCATION FOR DEVELOPMENT AFRICA FORUM (CAFOR)

\section{General overview and prospects for Africa}

\section{Introduction}

Africa is the second largest and second most-populated continent in the world with an estimated population of 1.2 billion (World Population Review, 2019). It also has the most youthful and fastest growing population globally. More than 40 percent of Africans are under the age of 15, and 20 percent are between the ages of 15 and 24 (UN, 2015). We estimate that by 2050, one-third of the world's population will live in Africa: up from about one-fifth in 2012. Such growth will be imbalanced across Africa with Southern and North African countries characterised by slowing or even negative youth population growth, while West Central, and East African countries will experience significant youth population increases (Nyamongo and Shilabukha, 2017). Sub-Saharan Africa will have a considerably higher youth-to-population ratio over the next 35 years. The continent must, therefore, be ready for an increasingly young labour force.

Africa is currently just at the beginning of this demographic transition. Advances in healthcare and well-being have led to increased life expectancy and improvements in infant and child mortality rates. Fertility rates are also projected to fall as socioeconomic well-being increases but following a time lag. The result is an interim period of rapid population growth, which we now characterize as the 'youth bulge'. While there are considerable variations across the continent, Africa will continue to have a young workforce for this century. A good understanding of how young job-seekers engage with labour markets is crucial.

The 'youth bulge' may be concentrated in West, Central and East Africa, but young people in North Africa and Southern Africa continue to face high levels of low-wage temporary jobs that compound their poverty and sense of inequality. The rates of unemployment are higher in urban areas than in rural areas although they can also generate faster economic growth. Youth migration has contributed to the urban crisis. Opportunities are quite low for rural youths. Therefore, increasing opportunities for rural youths can help curb the urban crisis. Despite the relatively rapid economic growth, inadequate job creation for a 'youth bulge' of Africans with few skills relevant to the labour market and an underperforming educational system 
has failed to prepare young people for existing jobs. There is also a significant gender discrepancy emerging as young women tend to enter marriage early and withdraw from the labour force and focus on rearing a family. Africa's widespread youth unemployment threatens to undermine social and political stability and means that young people are particularly vulnerable to radicalization (Atta-Asamoah, 2016).

\section{Recent developments in Africa are spanning from economic growth}

Africa's current economic growth is generating interest among global investors and is changing age-old perceptions of the continent as stagnant, high-risk and weak. Sub-Saharan African economies are expected to post an average growth rate of close to six percent in the next decade - exceeding the projected average of any other world region (FocusEconomics, 2019; The World Bank, 2018). Today we witness the highest flows of capital into the African continent. There has been a rise of Foreign Direct Investment from $\$ 10$ billion in 2000 to nearly $\$ 80$ billion in 2010. The United Nations tells us that this should by now have increased to over $\$ 150$ billion (UN, 2017).

Africa has benefited from steady flows of commodity-driven growth in the past (World Economic Forum, 2016). However, all indications are that the continent's current economic expansion is qualitatively different from the growing emissions of the past. Some of the most critical constituents of this growth have been high commodity prices, which have been propelled by enduring high demand from China and other emerging markets, as well as new sources of energy and mining production. The paradox here is that several African countries remain heavily reliant on the revenues from unprocessed commodities. What is also important here is that the African continent's recent surge has been sectors outside of extractive industries. These include construction, transportation, telecommunications and wholesale and retail as well as financial services. Finally, Africa's consumer base, propelled by rapid urbanization and rising incomes, is expanding rapidly, with consumer spending projected to grow from $\$ 860$ million in 2008 to $\$ 1.4$ trillion by 2020 (Leke et al., 2010).

Not all countries have been pulled along by Africa's "rise" and several - impoverished, land-locked or poorly governed - will likely remain fragile and stagnant (Cooke \& Downie, 2014). Nonetheless, the decisive issue here is that many African governments are rising to the challenge, and an increasing number are beginning to struggle more systematically with long-standing impediments to growth. Across these challenge areas, there are new opportunities and examples of positive progress that suggest how corporate and public actors can collaborate to over-

Sub-Saharan African economies are expected to post an average growth rate of close to six percent in the next decade - exceeding the projected average of any other world region. 
come barriers to investment and structural transformation. Moreover, in partnership with private investors, governments are more actively seeking to address the linkages between investment, growth, local employment, skills transfer and value addition.

\section{The challenges}

There are complex challenges that African governments need to address successfully. African governments must overtly prove a strategic vision for growth and social development, as well as collaborative partnerships and long-term commitment (Newsday, 2017). If Africa fails to challenge these impediments, this will leave African economies unprepared to capitalize on the critical opportunities that will arise in the coming decades for industrial growth, diversification and fuller integration into global supply chains. The enormous challenge of generating employment for the continent's growing youth population makes this task even more urgent. An estimated 12 million young Africans will join the labour pool every year, over the next decade (African Development Bank Group, 2016), according to the World Bank. Without vastly expanded opportunities in agriculture and manufacturing, governments will face increasing and possibly destabilizing pressures from a frustrated and underemployed citizenry.

African governments must ensure the equitable distribution of the benefits of growth and transformation. They must also ensure that these translate to improved well-being of citizens, including the most vulnerable. For this to materialize successfully, governments will need to enforce regulations and other enforcement capacities to ensure that private-sector players adhere to acceptable standards in labour practices, environmental stewardship, integrity and transparency. African governments will also need to have sound revenue collection and management systems to support public investments that may not be commercially bankable but that serve vulnerable populations for the broader public good. Moreover, and most important, it will require accountable, transparent governance, a culture of open service among political leaders and influential domestic constituencies to hold institutions and investors to account. For all the optimism around Africa's rise, these broader objectives will ultimately be the measure of success.

The World Bank estimates that Africa has more than 200 million people between the ages of 14 and 24 which makes it the world's "youngest" continent (Dewan and Bernhardt, 2012). This figure should double by 2045 . There is considerable apprehension about what this demographic youth bulge may mean for political stability and development if economic opportunities are not available. This possibility should spur African leaders to tackle the obstacles to structural economic transformation power generation, infrastructural development, regional integration - with far greater urgency. But leaders should also look to Africa's youth cohort as a potential engine of growth and development, innovation and entrepreneurship, particularly as workforces in other parts of the world - China and Europe, for example - age. 


\section{Opportunities for African economies}

Many African economies are at a turning point with no limits to available opportunities for sustained growth, structural change and accelerated development (Toh, 2016). Each African country is facing its unique set of economic, political and social circumstances. There can never be a single formula for success. However, across the 48 states of sub-Saharan Africa, we note three priority areas. These are:

- Infrastructure development needs acceleration: African countries will have to build an industrial base, draw much-needed investment, and compete in the global economy. To do so, businesses and citizens will need to have access to reliable, affordable electricity and a communication and transportation infrastructure that allows efficient and cost-effective movement of goods, labour and services. Linkages of African markets to one another and the global economy are crucial now more than ever before. (World Economic Forum, 2013)

- Economies need integration: Most African economies are too small to diversify and develop a competitive manufacturing base without expanding trade links to regional markets and deepening integration. As significant, potentially transformative investors consider basing operations in Africa, they will need relatively easy, efficient access to more extensive regional markets, supply chains and labour pools, if their investments are to be economically viable. (Twarmagazine, 2016)

- Africa's Workforce must be capable: Education is crucial for African economies to progress and lay the foundation for more sophisticated and competitive manufacturing and services capacity. African governments will need to invest adequately in educating their young citizens to have competent and capable participants in their future workforce. (Kirba, 2014)

\section{Capacities for planning in Africa}

Capacity development is a broad notion which is also a change process at the level of individuals, organisations and societies. Developing capacity is also about the many ways of sustaining capabilities, like Technical Cooperation, working with Non-State Actors, promoting multi-stakeholders processes and knowledge sharing.

Africa has good development plans at continental, sub-regional and national levels but efforts to implement these plans are being stumbled by severe capacity deficits often in the form of shortage of critical skills, deficiencies in leadership, inhibiting mindsets and weak institutions. The continent's skills shortage is acute in critical areas such as Science, Technology, Engineering and Mathematics (STEM) as well as in Agriculture (The STEM Workforce Challenge, 2007). Many initiatives are currently being undertaken to create and enhance capacity at varying levels. These include plans and programs from government, inter-governmental and non-governmental organisations to address capacity problems in many of Africa's lop-sided development enterprises. We know that the administrative capabilities of almost all countries in sub-Saharan Africa were weak at the time of independence, with weak human, institutional and organisational capacities. (The World Bank, 
2016) Over time, such abilities further weakened with a multiplicity of policies that included the implementation of policy agendas of the donor community during the 1980s and 1990s. Also, many African governments lacked the foresight to express concern about the long-term development imperatives of their respective countries, sub-regions and the region as a whole in the 2000s.

\section{Development Planning in Africa}

1. Development planning has a long and complex history in Africa, with the continent's development course witnessing different methods and approaches from the 1960s when many sub-Saharan countries attained nationhood. Development planning in Africa started in the early 1960s with a centralised type of planning spanning from a three to a five-year planning phase. There were at least thirty-two African countries that produced a national development plan during the 1960s. This first generation of development plans continued to the 1980s (Lopes, 2013). These plans promoted state-engineered economies with resources allocated by governments. It was notably the time of state-owned enterprises operating in most of the productive sectors. Still, Africa's development plans of the 1960s met with limited success. There were many reasons for this. In the first place, plan documents had shortcomings. Also, countries failed to implement these plans because of ambitiously formulated targets. Moreover, there were institutional and bureaucratic weaknesses resulting in extreme shocks and other political factors

Extensive neglect of home-grown planning under neoliberal Structural Adjustment Programmes (SAPs) marked the second phase in the evolution of planning in Africa. (Tsoungui et al., 1995) These SAPs emerged in the 1980s-1990s with the support of the Bretton Woods Institutions - the IMF and the World Bank. The primary goal of SAPs was to decrease the role of the State in production and service delivery. SAPs emphasised macroeconomic stability, the downsizing of public sector institutions, privatisation and cutting government spending and budget deficits (Grigsby and Perez, 2007). SAPs resulted in grave consequences for each country affected by massive social costs. The downsizing of the public-sector institutions and massive privatisations led to net job losses. The budget restrictions that went with SAPs compromised social service delivery and human capital development. Most importantly, SAPs failed to generate the expected growth outcomes as the annual economic growth for Africa over the 1990s averaged only 2.1 percent. (Soludo and Mkandawire, 2003)

2. What this proved to us all was that even the best-written development plans cannot succeed without an enabling domestic and external environment, backed up by institutional capacities and resources for implementation. The challenges that African countries have experienced in the execution of their development plans vary by state and period. But in general, the discontinuities and distractions in plan implementation coupled with the dysfunctional institutional architectures, and weak institutional capacities have played a critical role in undermining the

\section{Hungarian Journal of African Studies (Afrika Tanulmányok)}


success of development plans in Africa. Also, the tenuous links between resource allocation and development priorities with overdependence on external resources and weak relationships between national and sub-national planning and implementation processes have also contributed grossly in sabotaging development plans on the continent (Ali, 2011). Discontinuities and distractions prompted by conflict, constitutional and unconstitutional regime changes have often derailed the implementation of development plans in Africa. An excess of externally imposed agendas and conditions that have consistently closed or narrowed down the policymaking space made matters worse. Undemocratic regime changes have been driven by conflict and coups d'état. Africa has seen at least 200 successful and failed coups since the 1960s (Al Jazeera. 2015).

Institutional arrangements for development planning in Africa have generally been dysfunctional, resulting in weak coordination between central planning bureaus, ministries of finance and other line ministries, and the failure to align resources with national priorities. Strong coordination between central planning agencies and ministries of finance is a prerequisite for aligning financial resources with national development priorities. Disproportionate power relations between central planning bodies and ministries of finance have unfortunately weakened planning agencies' capacity to fulfil their role in coordinating the planning process and ensuring the alignment of the programmes and projects of implementing agencies with the priorities of national development plans (Ngwenya, n.d.). Experiences in African countries suggest that there is no onesize-fits-all solution to the role of the central planning agency. But to the extent that the finance ministry remains the "super ministry", planning will continue to be subservient to finance. African countries need a credible mechanism that assigns equal importance to finance and planning in the governmental hierarchy (UNDP Technical Support Team, n.d.). Explicit support from the highest level of government will be necessary in such a case, as in Malaysia, or by placing control of budgeted expenditure in the hands of the central planning agency. The latter option requires excellent coordination, to ensure the due consideration of the recurrent cost implications of all capital account expenditures.

Weak capacities in the use of planning tools have also contributed to implementation setbacks. For effective planning to take place, there must be cooperation between national and sub-national institutions and actors in the implementation process. Sub-national participation enhances comprehensive planning and facilitates continuity in the planning process. The implementation of development plans in Africa has, however, suffered from challenges in synergising national and sub-national systems. While there has been a shift toward more decentralised approaches to implementation, national and sub-national institutions have often not been adequately integrated into development programmes.

3. Human capacity challenges: There are two dimensions that we can identify with the human capacity challenge of Africa. First, there is a shortage of jobs to sat- 
isfy the demands of an increasingly ambitious and expectant generation of young people. Much of this is due to the structural underdevelopment of African economies, which continue to rely on primary commodities' production and export and capital-intensive extractive industries. While the official unemployment rate was $8.3 \%$ in 2011 (now over 12\%), $70 \%$ of the African workforce was classified by the UN Economic Commission for Africa as being in vulnerable employment (ECA, 2017). Without accelerated growth, economic diversification and expansion of more labour-intensive sectors such as agri-business and manufacturing, this problem will not be resolved quickly as young populations continue to grow. Poor education could leave a generation of young school and college leavers without the skills required for them to compete in an increasingly competitive global digital marketplace (Karar and Pietersen, 2009).

At the same time, there is a shortage of suitably qualified workers to fill the limited number of skilled jobs available, stemming in large part from long-standing deficits in primary and secondary education systems in the majority of African countries, which are failing to turn out sufficient numbers of suitably qualified graduates. Africa lags badly behind the rest of the world in school attendance and educational performance (UNESCO Education 2018). School enrolment has risen dramatically in the last 20 years, but education deficit remains large compared with other parts of the world. In 2011, 22 percent of Africa's primary school-age children were out of school, compared with 11 percent in Arab states, seven percent in South and West Asia and five percent in Latin America and the Caribbean (UNESCO Institute of Statistics, Jan 2014). Africa has the lowest level of secondary school attendance as well, with 34 percent enrolment, compared with 65 percent in Arab states and 90 percent in Latin America (UNESCO, GMR 2010). Some seven percent of college-age youth are enrolled in a university in Africa, compared to 30 percent in the rest of the world.

\section{Remedies to these challenges: the PRSPs and NDS etc.}

Due to these experiences in planning, policymakers and decision-makers learnt considerably with better information about the need to develop a more comprehensive agenda for public sector reforms. They were also able to look into the importance of good institutions in the development process, especially in the new context of globalisation.

In the early 2000s, SAPs were replaced by Poverty Reduction Strategies (PRSPs), which aimed at reversing the adverse effects of a decade of Structural Adjustment on welfare and social conditions. PRSPs emphasised strongly on reducing poverty as

In the early 2000s, SAPs were replaced by Poverty Reduction Strategies (PRSPs), which aimed at reversing the adverse effects of a decade of Structural Adjustment on welfare and social conditions.

\section{Hungarian Journal of African Studies (Afrika Tanulmányok)}


a condition for debt relief. Several African countries undertook PRSPs for at least two generations, with the aim of ensuring their eligibility for debt relief. However, many lacked credibility as the whole process was again externally driven, even when at the back of minds there was always the notion of ownership and consultations to strengthen PRSPs. Furthermore, PRSPs tended to place unbalanced emphasis on the social sector at the expense of the productive industry thereby raising questions about the sustainability of the poverty reduction agenda (IMF, 2016). There has recently developed a keen interest in, and a return to, more comprehensive development plans that go way beyond PRSPs, which many see as short-sighted. Indeed, several African countries have adopted long-term development visions and planning frameworks with far more aggressive growth and social development objectives.

The National Development Strategies (NDS) have now gone beyond the narrow objective of poverty reduction to encompass goals such as accelerated growth, employment creation, structural transformation and sustainable development. Contrary to what we witnessed in the 1960 s, these plans engage a combination of state and market-based approaches. They also appreciate the critical role of both the public and the private sector in the development process (UNESCO, 2016).

Many African countries have developed Long Term Visions to guide their steps towards these ambitious objectives (Lopes, 2013). These long-term visions want to ensure that African actors assume stronger ownership as well as a more consultative and participatory process that would involve a broad spectrum of stakeholders. These will include civil society, the private sector, varying decentralised constituencies and development partners. These more extensive national development plans often take into consideration various global and continental development goals and frameworks such as NEPAD, which has since July 2018 become the African Union's Development Agency.

\section{Monitoring national development plans}

Monitoring and evaluation systems in Africa have improved over time but can still be considered immature and evolving (Porter and Goldman, 2013). Donor reporting requirements and conditions have generally often driven monitoring and evaluation activities on the continent. Most African countries are yet to fully own and appreciate the importance and relevance of monitoring and evaluation of evidence-based policymaking. The findings of monitoring and evaluation reports are consequently not fully exploited to inform and improve policymaking and budget allocations. But beyond internalising the culture of monitoring and evaluation, monitoring systems in Africa tend to be fragmented, suffering from weak institutional capacities and lacking robust statistical methods to provide the data necessary for control. There is also a disproportionate focus on expenditure tracking and activity level monitoring, as opposed to results-based monitoring. Furthermore, national and sub-national monitoring systems are often not integrated, which often omits essential information about local level performance in plan implementation. In most cases, institutional mechanisms exist only in theory with the lack of commitment and capacities hampering them. 


\section{Planning for Africa's transformation agenda - AU Agenda 2063, SDGs and CESA 16-25}

\section{The transformation agenda}

Africa has a transformation agenda, which it is pursuing, under the recognition of the African Union's vision of "an integrated, prosperous and peaceful Africa, driven by its citizens and representing a dynamic force in the global arena" (African Union, 2014.). Therefore, success will be elusive unless we purposefully harness the potential of the continent's young people, and taking into account all the planning-related issues raised in this paper. African leaders have given credibility to this view by identifying youth development and science, technology and innovation as the main pillars of Agenda 2063. I have already talked about how the African continent is today engulfed in what we now call the 'youth bulge' as the demographics on the continent change with many obvious challenges. I have also intimated that these challenges surface more in the education systems, where the question of relevance is increasingly becoming the subject of much conversation, as Africa's widespread youth unemployment threatens to undermine social and political stability with many young people becoming particularly vulnerable to radicalisation. The question now is how we as Africans can do better by reasserting the importance of planning and embarking on a different path to recreate and enhance existing capacity for efficient development through our education systems in this demographic transition.

Agenda 2063 is the African Union's Fifty-Year Vision and Action Plan for "the Africa that Africans want". Agenda 2063 is calling for action by all segments of society to work together and build a prosperous and united Africa "based on shared values and a common destiny". It is a strategic framework for the socio-economic transformation of the continent over the next 50 years. It builds on and seeks to accelerate the implementation of past and existing continental initiatives for growth and sustainable development.

\section{Science, Technology and Innovation}

The Science, Technology and Innovation Strategy for Africa (STISA-2024) developed during the critical period when the African Union was formulating its broader and long-term AU Agenda 2063. This strategy is to "accelerate the transition of African countries to innovation-led, and knowledge-based economies", by improving science, technology and innovation readiness in Africa and implementing specific policies and programmes in these areas which address societal needs holistically and sustainably (African Union, 2014b).

The STISA-2024 is the first of the ten-year incremental phasing strategies to respond to the demand for science, technology and innovation to impact across critical sectors such as agriculture, energy, environment, health, infrastructure development, mining, security and water among others. The strategy anchors firmly on six distinct priority areas that contribute to the achievement of the AU Vision. These priority areas are: Eradication of Hunger and Achieving Food Security; 
Prevention and Control of Diseases; Communication (Physical and Intellectual Mobility); Protection of our Space; Live Together-Build the Society; and Wealth Creation (African Union, 2014b).

The strategy further defines four mutually reinforcing pillars which are prerequisite conditions for its success. These pillars are building and upgrading research infrastructures; enhancing professional and technical competencies; promoting entrepreneurship and innovation; and providing an enabling environment for STI development in the African continent (African Union, 2014b). The AU contends that STI will design, implement and synchronise continental, regional and national programmes to ensure that their strategic orientations and pillars are mutually reinforcing, to achieve the envisaged developmental impact as effectively as possible.

\section{Education as a top priority}

Education remains a top priority in Africa and is now contributing tremendously to the strengthening of capacities in various disciplines. It plays a pivotal role in enabling the continent to achieve the aspirations it laid down in its people-centred and long-term transformative change - Agenda 2063, through the development of competent and productive human resources. The global 2030 Sustainable Development Goals (UN Women, 2017) put strong emphasis to "ensure inclusive and quality education for all and promote lifelong learning". There is also the African Union's Continental Education Strategy for Africa 2016-2025, also known as CESA 16-25 (African Union Commission, 2017). It is through a strong political will and motivation that CESA 16-25 is premised to lift a large section of Africa's population out of poverty, reduce inequalities, gender disparity and empower the African citizens to be innovative, address continental challenges and promote global competitiveness. CESA 16-25 creates a conducive learning environment at all levels including informal and non-formal settings, while in the process revitalises education systems, and ensures quality and relevance. It further promotes access to education by reaching large numbers of students and professionals and taking advantage of nonconventional methods such as the use of technologies and ICTs. Strategic partnerships are key to the implementation of CESA 16-25. The African Union has set up a Committee of Ten Heads of State and Government Champions for Education, Science and Technology. The African Union has also established the Pan African University and has set up its E-University. The Union is also expanding Technical and Vocational Education and Training (TVET) opportunities at both secondary and tertiary levels, and also institutionalise the School Feeding programme which the African Union celebrates on every $1^{\text {st }}$ of March. Such is Africa's journey towards 2030 and beyond to 2063 for "the Africa we want" (UN Office of the Special Advisor for Africa, 2016).

\section{Strategic partnerships}

Through these strategic partnerships, those responsible for the implementation of CESA 16-25 are assigned to "reorient Africa's education and training systems to 
meet the knowledge, competencies, skills, innovation and creativity required to nurture African core values and promote sustainable development at national, subregional and continental levels". The goal of CESA 1625 lies on the creation of a new context favourable to the full inclusion of education among the priorities of the $\mathrm{AU}$, the RECs and member states. To this end, the African Union will examine and address the current communication gaps. These will include looking into the actual differences between ratifications, domestication and implementation of the various treaties on education, as well as the insufficient commitment on the part of governments to fully implement policies and plans in pursuit of the international targets of the SDGs, Agenda 2063 and CESA 16-25.

The African Union will work with traditional partners and will also emphasise on South-South cooperation for the implementation of the agendas (African Union, 2016). The AU will also ensure political leadership in the orientation and agenda setting of the activities of CESA 16-25, emphasising on communicating the principles of the Continental Strategy well to its member states and at the international level. The AU will also ensure the choice of priorities in investment and action, the formulation and adoption of the implementation of programs and projects, the mobilisation and the distribution of resources, and the monitoring and validation of results (RACA Report of Annual Continental Activities - African Union Commission HRST Department, 2017).

\section{New challenges}

Some challenges remain. These constitute ensuring that we have credible consultation processes. We must also prioritise our funding and keep it in line with our continental development aspirations. Donor coordination is another area that needs greater attention as Africans can no longer leave their fate to be decided by external donors. Finally, we must strengthen capacities at all levels and ensure proper implementation of projects and programmes, and develop active monitoring and evaluation systems that feedback into the policymaking process.

\section{Planning implementation of global agendas at the national level}

Planning experiences in many African countries point to some overarching and specific guidelines for development planners and policymakers.

We may bear the following issues in mind as we attempt to ensure that planning and implementation take place at the country level.

- "Development planning is vital for developing countries because the task of addressing market failure should not go to the invisible hand of the market.

- There is no substitute for an active and committed leadership to guide development planning in Africa. Such administration also must act to ensure inclusiveness and to involve all stakeholder groups. Moreover, commitment and ownership are of critical importance for good leadership.

- There is no one-size-fits-all approach to development planning. Strategies that work for one country may not necessarily work for another. Furthermore, for any 
given country, procedures that work at one point in time may not be appropriate at another point in time.

- Stability is critical for successful planning. Discontinuities, including those caused by regime changes and changes of government, have contributed to implementation failures in Africa.

- Political commitment is crucial for nurturing a healthy central planning establishment. The primary stages of the planning process call for this as the effectiveness of the central planning body will depend on the political commitment to nurture and sustain it.

- A country can rely on aid while owning and leading its development process by constructing a sound development plan with a clear set of priorities and assigning donors to specific sectors of development. The country must also have a firm commitment to the defined development goals.

The specific planning-related guidelines fall into the following three categories: comprehensive planning, effective planning and corrective planning." (UNECA, 2016: XIV-XV)

\section{Comprehensive planning enhances sustainability and can avert social unrest}

- "Establishing traditional mechanisms for stakeholder engagement promotes and sustains inclusiveness.

- Large private companies should be given an essential role during consultations to design a development plan, as private sector associations do not always represent the full range of opinions within the sector.

- Predetermining a development agenda undermines the integrity of the consultation process.

- Restricting the scope for consultation on the macroeconomic framework is counterproductive and undermines ownership.” (UNECA, 2016: XV)

\section{Effective implementation}

- "Central planning agencies must be assigned equal importance to finance ministries, to ensure the effective coordination and alignment of resources with development priorities.

- In designing a development plan, the central Government should provide broad guidance, and should then leave it to the lower levels of Government to develop detailed strategies for implementation.

- Decentralized approaches to planning promote grassroots participation and enhance continuity in plan implementation." (UNECA, 2016: XV)

\section{Corrective planning: monitoring and evaluation}

- "The coordination of a decentralised monitoring and evaluation system is the necessary precondition for satisfactory achievements in plan implementation; integrated monitoring and evaluation systems are key to the avoidance of frag- 
mented planning implementation. Monitoring and evaluation systems must orientate to both domestic stakeholders and development partners." (UNECA, 2016: XV)

\section{More work to improve planning}

In short, more action is required to develop the planning frameworks in Africa to translate development aspirations and priorities into concrete results. We suggest further work in the following areas:

- Support the strengthening of national capacities to design, implement and monitor useful planning frameworks.

- There still exists data challenges. The effectiveness of national planning systems hinges mostly on the availability and quality of data. Reliable data are essential to inform the setting of priorities and to facilitate the tracking of performance.

- Another vital aspect is coordination. Coordination is essential between ministries of finance and the ministries or entities in charge of development planning, among others. Such coordination will ensure better linkages in the planning cycles to those of the budget, and hence providing effective implementation of the national development plan.

- We can also leverage our development planning capacities by developing mechanisms for peer learning and experience sharing.

- A network of development planners that includes an electronic platform that will serve as a repository of literature current research related to development planning is necessary. This platform will also include forums for discussion and exchange of ideas and experiences related to all aspects of the plan.

- Africa's rough experience with development planning in the past is ceding ground to a more positive outlook for the future. Indeed, there are some excellent examples of success stories among African countries, which graduated from low-income countries to middle-income countries (Cape Verde, Ghana, Zambia, and Botswana).

- Also, some African countries such as Ethiopia, Nigeria and Uganda have adopted long-term development visions and planning frameworks with far more aggressive growth and social development objectives with further detailed policies and strategies than what we typically see in PRSPs. (Based on Lopes, 2013)

\section{Keys to success}

(a) Encourage training collaborations: Large investors that are looking strategically at Africa have a strong incentive in building up the skill sets of potential employees to maximise commercial efficiency, and some companies are investing in collaborative partnerships with governments and educational institutions. More governments and private companies are looking to collaborate to expand training opportunities for midcareer officials and personnel in technical areas such as procurement, management and planning.

(b) Build regional labour pools: A core element of regional integration and economic competitiveness is the ability of labour to move smoothly across borders. 
Visa requirements for intra-African migration are among the most restrictive in the world (African Development Bank Group, 2013). Large international companies that are looking at long-term engagement in Africa are willing to make considerable investments in local workforce development. But for newer players, in sectors that are less commercially certain, the substantial up-front investments in training and the constraints on hiring top-line personnel may serve as a deterrent. Visa restrictions and local content regulations limit opportunities to draw on a larger talent pool but also cost national economies in long-term competitiveness.

Intraregional labour mobility and local hire requirements are often politically charged issues, as policymakers seek to protect domestic employment opportunities. But restricting cross-border movement may also limit the entry of regional entrepreneurs and investors who can create jobs, bring expertise and know-how, and help develop new industries. Ultimately, the onus remains on African governments to be strategic and balanced in setting the terms of their relationship with international companies and investors, and these decisions must reside on sound analysis and understanding of short- and long-term consequences.

(c) Reach out to the diaspora: The African diaspora offers a significant pool of talent and technical expertise that can be harnessed to build capacity on the continent (Benton, 2007). As Africa's fortunes continue to rise, many in the diaspora are looking at investment and employment opportunities in their countries of origin, with global firms benefiting. Many in the African diaspora have the technical and managerial skills their home countries lack and can further support economic growth through their knowledge of foreign private sectors. Many programmes shape around short-term stints in the state of origin, for example, the Ethiopian North American Health Professionals Association, which works to support health care in Ethiopia through biannual missions and transfer of knowledge, skills and state-of-the-art technology (Ethiopian North American Health Professionals Association Inc., n.d.).

(d) Invest in the workforce of the future: Africa is not in reality short of talented individuals with entrepreneurial skills and business know-how. But investors often cite the lack of managerial and leadership skills, as well as a shortage of STEM skills (science, technology, engineering and mathematics) among the African workforce.

A central priority, if African governments are to lay the ground for long-term sustained growth and competitiveness, must be to improve the accessibility and quality of education at primary and secondary levels. Learning availability with quality is a fundamental requirement to nurture and build a pool of graduates with solid practical skills, capacity to adapt to new industries and a grounding in national development priorities. With increasing constraints on public funding and foreign development assistance, expanding both the reach and quality of the educational system will be a significant challenge and a fiscal burden. But the longer-term costs 
of failed education systems should prompt greater urgency in finding efficiencies, strengthening quality assurance and oversight, and looking to new technologies and partnerships to expand educational opportunities.

Several new initiatives are underway to boost tertiary education levels in Africa at the regional level. I have already mentioned the Pan African University (Pan African University, n.d.). This university was launched by the African Union in 2011, creating centres of excellence at regional hub universities open to high-performing students from across Africa, in fields like science, technology, energy and earth sciences. The World Bank has taken a similar regional approach, working to strengthen elite higher education institutions in West and Central Africa to concentrate more on training and applied research in areas such as water, infrastructure, hospitality industries, banking and information and communication technology, the sectors of growth and opportunity in the coming decades (The World Bank, 2017).

\section{The path ahead}

African governments have a window in which to prepare the ground for long-term growth, and maximise current investment and finance opportunities, as well as make the up-front investments that will drive economic transformation. Our governments in Africa, the private sector and civil society all have a role to play. The government must help push the process through a clearly articulated long-term vision. Such a course must constitute a business environment that promotes economic competitiveness, regulatory rules and enforcement capacities that protect citizens and the environment. Governments must also have a robust investment in the well-being and education of their citizens. Private investors, too, should look to the long-term if they want to accelerate and ultimately benefit from the great opportunities on the horizon. Universities, think tanks and advocacy groups can play a critical role in providing strategic analysis and vision, informing public debate and highlighting emerging models of progress and success. And African citizens themselves can build constituencies for reform and oversight that ensure that benefits and opportunity get equitable distribution and which hold government and private sector to account.

Africa is at an exciting stage in its development journey, and the expectations are that the continent will soon become a new pole of global growth. Africa must, nevertheless, continue to plan its development trajectory and also increase its policy space. The continent's leaders must make prudent decisions about the appropriate strategies that the continent will need to attain economic growth and structural transformation. Failing to plan means planning to fail. 


\section{Bibliography}

- African Development Bank Group. (2016). Leaders underscore urgent need to create jobs for African youth through agriculture, ICT, industry. https://www.afdb.org/en/news-and-events/ leaders-underscore-urgent-need-to-create-jobs-for-african-youth-through-agriculture-ictindustry-15724/ [02.02.2019]

- African Development Bank Group. (2013). Visa restrictions and economic consequences in Africa. https://www.afdb.org/en/blogs/afdb-championing-inclusive-growth-across-africa/ post/visa-restrictions-and-economic-consequences-in-africa-11987/ [02.02.2019]

- African Union. (2014). Agenda 2063. https://au.int/en/agenda2063 [02.02.2019]

- African Union. (2014b). Science, Technology and Innovation Strategy for Africa. http://africapolicyreview.com/science-technology-and-innovation-strategy-for-africa-2024-stisa-2024/

- African Union. (2016). Implementation of the Continental Education Strategy for Africa. Planning Meeting June 2016, http://download.ei-ie.org/Docs/WebDepot/ConceptPlanningMeeting CESA16-25.pdf [02.02.2019]

- African Union Commission (AUC). (2018). Africa's Development Dynamics 2018: Growth, Jobs and Inequalities. Organization for Economic Cooperation and Development (OECD), https://read.oecd-ilibrary.org/development/africa-s-developmentdynamics-2018_9789264302501-en\#page1 [02.02.2019]

- African Union Commission. (2017). Continental Education Strategy for Africa 2016-2025. CESA Journal Online, https://au.int/sites/default/files/documents/33863-doc-cesa_journal_ vol2 final.pdf [02.02.2019]

- African Union Commission, Human Development, Education, Science Technology and Innovation, and Youth, Report of Annual Continental Activities, 2017 - RACA 2017.pdf.

- AIMS. (2019). The Science, Technology \& Innovation Strategy for Africa 2024 (STISA-2024). AOSP \& AGORA efforts in support of its implementation through facilitation of relevant data access. https://au.int/sites/default/files/newsevents/workingdocuments/33178-wd-stisaenglish_-_final.pdf

- Al Jazeera. (2015). Why are coups common in Africa? https://www.aljazeera.com/programmes/insidestory/2015/09/coups-common-africa-150917161949909.html [02.02.2019]

- Ali, A. A. G. (2011). Development Planning in Africa: Key Issues, Challenges and Prospects. UN Economic and Social Council, https://www.uneca.org/sites/default/files/ uploaded-documents/CoM/cfm2011/com2011_developmentplanning-inafricakeyissueschallengesandprospects_en.pdf [02.02.2019]

- Ali, M. (2014). Youth unemployment: A global security challenge, Harvard International Review, http://hir.harvard.edu/article/?a=7296 [02.02.2019]

- Atta-Asamoah, A. (n.d.). Youth of Africa: Unemployment, social cohesion and political instability. UNICEF, https://www.unicef-irc.org/article/1060-youth-of-africa-unemploymentsocial-cohesion-and-political-instability.html [02.02.2019]

- Beegle, K., Christiaensen, L., Dabalen, A. and Gaddis, I. (2016). Poverty in a Rising Africa. The World Bank.

- Benton, S. (2007). Harness African diaspora's expertise to benefit continent. https://www.skillsportal.co.za/content/harness-african-diasporas-expertise-benefit-continent [02.02.2019]

- Cooke, J. G. and Downie, R. (2014). Africa at a Crossroads - Overcoming the Obstacles to Sustained Growth and Economic Transformation. CSIS, https://csis-prod.s3.amazonaws. com/s3fs-public/legacy_files/files/publication/140417_Cooke_AfricaAtCrossroads_WEB. pdf [02.02.2019]

- Dewan, S. and Bernhardt, J. (2012). Creating Just Jobs Must Be Our Top Priority. Center for American Progress, https://www.americanprogress.org/issues/economy/ news/2012/11/15/45121/creating-just-jobs-must-be-our-top-priority/ [02.02.2019]

- Ethiopian North American Health Professionals Association Inc. (n.d.) https://www.guidestar. org/profile/38-3520786 [02.02.2019]

- FocusEconomics. (n.d.). https://www.focus-economics.com/ [02.02.2019] 
- FocusEconomics. (2019). Sub-Saharan Africa Economic Outlook, 2018. https://www.focuseconomics.com/online-store/products/annual-subscription/sub-saharan-africa [02.02.2019]

- Grigsby, V. A. H. and Perez, F. J. (2007). Structural Implications of Economic Liberalization on Agriculture and Rural Development. RuralStruc Program - Phase I, Jan 2007. http://siteresources.worldbank.org/AFRICAEXT/Resources/RuralStruc-NICARAGUA_phase1.pdf [02.02.2019]

- IMF. (2016). Poverty Reduction Strategy Papers (PRSP). www.imf.org/external/np/prsp/prsp. aspx [02.02.2019]

- Karar, E. and Pietersen, K. (2009). Challenges for human capital development and technological innovations in the South African water sector. Development Bank of Southern Africa, Development Planning Division Working Paper Series No. 13, https://www.dbsa.org/EN/ About-Us/Publications/Documents/DPD\%20No13.\%20Challenges\%20for\%20human\%20 capital $\% 20$ development $\% 20$ and $\% 20$ technological $\% 20$ innovations $\% 20 \mathrm{in} \% 20$ the $\% 20$ South\%20African\%20water\%20sector.pdf [02.02.2019]

- Kirba, D. (2014). The challenging opportunity of Africa's rising workforce. https://www.devex. $\mathrm{com} /$ news/the-challenging-opportunity-of-africa-s-rising-workforce-84628 [02.02.2019]

- Leke, A., Lund, S., Roxburgh, Charles and Wamelen, A. (2010). What's driving Africa's growth. McKinsey \& Company, https://www.mckinsey.com/.../whats-driving-africas-growth [02.02.2019]

- Lopes, C. (2013). 50 years of Development Planning in Africa: Retrospect and Prospects. South Centre, https://www.southcentre.int/question/50-years-of-development-planning-inafrica-retrospect-and-prospects/ [02.02.2019]

- Munang, R. and Mgendi, R. (2004). Addressing the Youth Bulge in Africa. This is Africa, Fresh Insights on Africa by Africans, www.thisisafrica.me [02.02.2019]

- Newsday. (2017). Role of government in addressing Africa's business challenges. https://www. newsday.co.zw/2017/08/role-government-addressing-africas-business-challenges/ [02.02.2019]

- Ngwenya, S. N. (n.d.). Institutional Arrangements and Policy Issues in Regional Co-Operation in the Transport Sector in Africa. http://unpan1.un.org/intradoc/groups/public/documents/ AAPAM/UNPAN026477.pdf [02.02.2019]

- Nyamongo, I. K. and Shilabukha, D. K. (2017). State of Africa's Population 2017. The African Union Commission, https://au.int/sites/default/files/newsevents/workingdocuments/32187wd-state_of_africas_population_-_sa19093_-e.pdf [02.02.2019]

- Pan African University. (n.d.). https://pau-au.net [02.02.2019]

- Persaud, A. (2016). Integrated Planning for Education and Development. Background paper prepared for the 2016 Global Education Monitoring Report, UNESCO \& Global Education Monitoring Report.

- Porter, S. and Goldman, I. (2013). A growing demand for monitoring and evaluation in Africa. African Evaluation Journal 1, 1-9.

- Soludo, C. C. and Mkandawire, T. (Eds.). (2003). African Voices on Structural Adjustment. IDRC, https://www.idrc.ca/sites/default/files/openebooks/888-0/index.html [02.02.2019]

- The STEM Workforce Challenge. (2007). Employment and Training Administration by Jobs for the Future. https://www.doleta.gov/youth_services/pdf/STEM_Report_4 07.pdf [02.02.2019]

- The World Bank. (2016). Development Policies, Institutions Improve in Few African Countries. http://www.worldbank.org/en/region/afr/publication/development-policies-institutions-improve-in-few-african-countries [02.02.2019]

- The World Bank. (2018). Global Economic Prospects: Sub-Saharan Africa. https://www. worldbank.org/en/region/afr/brief/global-economic-prospects-sub-saharan-africa-2018 [02.02.2019]

- The World Bank. (2017). Tertiary Education Overview. https://www.worldbank.org/en/topic/ tertiaryeducation [02.02.2019]

- Toh, K. (2016). Emerging Growth Economies in Sub-Saharan Africa. SAGE Journals, https:// journals.sagepub.com/doi/pdf/10.1177/0569434516652041 [02.02.2019] 
- Twarmagazine. (2016). The Need for African Economic Integration. http://twarmagazine. com/the-need-for-african-economic-integration/ [02.02.2019]

- Tsoungui et al. (1995). Structural Adjustment and Sustainable Development in Cameroon. Working Paper 83. https://www.odi.org/sites/odi.org.uk/files/odi-assets/publications-opinionfiles/7002.pdf [02.02.2019]

- UN. (2015). Youth population trends and sustainable development. POPFACTS 1, 1-4. http:// www.un.org/esa/socdev/documents/youth/fact-sheets/YouthPOP.pdf [02.02.2019]

- UN Office of the Special Advisor for Africa. (2016). Implementing Agenda 2063 and Agenda 2030 for Sustainable Development in an Integrated and Coherent Manner in Africa: Moving Forward (21 September 2016). https://www.un.org/en/africa/osaa/events/2016/mdgtosdgagenda2063.shtml [02.02.2019]

- UN Women. (2017). The Sustainable development Goals and Agenda 2063. https://sustainabledevelopment.un.org/content/documents/2441UNWomenSDGReport.pdf [02.02.2019]

- UNDP Technical Support Team. (n.d.). Needs of Countries in Special Situations - African Countries, Least Developed Countries, Landlocked Developing Countries and Small Island Developing States, as well as the specific challenges facing Middle-Income Countries. https:// sustainabledevelopment.un.org/content/documents/2080TST\%20Issues\%20Brief\%20on\%20 Countries\%20in\%20Special\%20situations_Final_14_Nov.pdf [02.02.2019]

- UNECA. (2011). Development Planning in Africa: Key Issues, Challenges and Prospects: A background paper. https://www.uneca.org/sites/default/files/uploaded-documents/CoM/ cfm2011/com2011_developmentplanning-inafricakeyissueschallengesandprospects_en.pdf [02.02.2019]

- UNECA. (1996). Overview of Economic and Social Development in Africa-ECA. https:// www.uneca.org/cfm1996/pages/overview-economic-and-social-development-africa [02.02.2019]

- UNECA. (2016). Planning for Africa's Development: Lessons, Insights and Messages from Past and Present Experiences. https://www.uneca.org/publications/planning-africa\%E2\%80\%99sdevelopment [02.02.2019]

- UNESCO. (2016). Swaziland 2016 report. National Development Strategy (NDS) 2022. https://en.unesco.org/creativity/policy-monitoring-platform/national-development-strategynds [02.02.2019]

- UNESCO. (2018). Global Education Monitoring Report 2018. Available at: https://en.unesco. org/gem-report/taxonomy/term/209

- UNESCO Institute of Statistics. (2014) World Inequality Database on Education 2014 Available at: https://www.education-inequalities.org/; https://en.unesco.org/gem-report/statistics

- World Economic Forum. (2016). 3 reasons things are looking up for African economies. https://www.weforum.org/agenda/2016/05/what-s-the-future-of-economic-growth-in-africa/ [02.02.2019]

- World Economic Forum. (2013). Strategic Infrastructure in Africa: A business approach to Project Acceleration. https://www.weforum.org/reports/strategic-infrastructure-africa [02.02.2019]

- World Population Review. (2019). Africa Population 2019. http://worldpopulationreview.com/ continents/africa-population/ [02.02.2019]

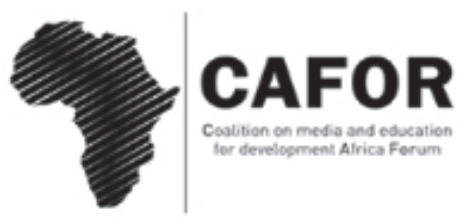

